\title{
Sikap Primigravida Pranikah terhadap Kehamilannya di Wilayah Kerja Puskesmas Taman-Sidoarjo
}

\author{
Nur Eka Roifah1, Tetty Rihardini²
}

1. Mahasiswa Program Studi D-III Kebidanan Universitas PGRI Adi Buana Surabaya

2. Tenaga Pengajar Program Studi D-III Kebidanan Universitas PGRI Adi Buana Surabaya

\begin{abstract}
ABSTRAK
Diperkirakan sekitar 200-300 juta kehamilan yang tidak diinginkan terjadi akibat perilaku seks bebas, khususnya di kalangan remaja. Remaja di Indonesia pun sudah mulai lebih bertoleransi terhadap gaya hidup seksual pranikah.Akibatnya terjadi peningkatan kehamilan yang tidak diinginkan di kalangan remaja. Penelitian ini bertujuan untuk mengetahui sikap primigravida yang mengalami kehamilan pranikah terhadap kehamilannya karena pengalamankehamilan pranikah yang dihadapimembentuk sikap positif ataupun negatif dari individu terhadap kehamilannya.

Jenis penelitianyang digunakan adalah penelitian deskriptifcross sectional, dengan penelitian populasi yang menggunakan seluruh populasi yang terdata sebagai sampel.Variabel yang diteliti dalam penelitian iniadalah sikap primigravida yang mengalami kehamilan pranikah terhadap kehamilannya dengan sampel 20 responden. Analisis data yang digunakan dalam penelitian ini adalah presentase. Penelitian dilaksanakan pada bulan Juni-Juli 2013 di wilayah kerja dari Puskesmas Taman-Sidoarjo.

Hasil dari penelitian ini dapat diketahui bahwa sikap primigravida yang mengalami kehamilan pranikah terhadap kehamilannya yakni 11 orang (55\%) menunjukkan sikap negatif (menolak) dan hanya 9 orang (45\%) menunjukkan sikap positif (menerima).

Diharapkan kepada keluarga dan masyarakat untuk tidak melakukan diskriminasi terhadap wanita yang mengalami kehamilan pranikah. Seharusnya keluarga dan masyarakat bisa membantu wanita yang mengalami kehamilan pranikah beradaptasi dengan kehamilannya sehingga tidak mempengaruhi kesehatan ibu dan janin.
\end{abstract}

Kata Kunci : Sikap, Primigravida Pranikah

\section{PENDAHULUAN}

Masalah kehamilan pranikah merupakan masalah dunia. Diperkirakan sekitar 200-300 juta kehamilan yang tidak diinginkan terjadi akibat perilaku seks bebas, khususnya di kalangan remaja (Manuaba, 2002).

Di Inggris 1996, angka persalinan per tahun pada usia 15-19 tahun mendekati 30 per 1000 wanita dan angka kehamilan keseluruhan pada kelompok usia ini (termasuk persalinan, terminasi kehamilan dan aborsi spontan yang datang ke rumah sakit) adalah 56,8 per 1000 wanita. Angka konsepsi remaja di Inggris adalah yang tertinggi untuk Eropa Barat. Angka tersebut kemungkinan besar lebih rendah daripada angka kehamilan sebenarnya, karena banyak wanita yang mengalami aborsi dini tidak datang ke rumah sakit (Glasier, 2006).

Remaja di Indonesia sudah mulai lebih bertoleransi terhadap gaya hidup seksual pranikah, misalnya penelitian yang dilakukan oleh berbagai institusi di Indonesia selama kurun waktu tahun 1993-2002, menemukan bahwa $5 \%-10 \%$ wanita dan $18 \%-38 \%$ pria muda berusia 16-24 tahun telah melakukan hubungan seksual pranikah dengan pasangan yang seusia mereka. Penelitian-penelitian lain di Indonesia juga memperkuat gambaran adanya peningkatan resiko pada perilaku seksual kaum remaja. Temuan-temuan tersebut mengindikasikan bahwa 5\%-10\% wanita muda usia 15-24 tahun yang tidak/ belum menikah, telah melakukan aktifitas seksual yang beresiko (Suryoputro, 2006). Akibatnya terjadi peningkatan kehamilan yang tidak diinginkan di kalangan remaja. Remaja yang melakukan kehamilan sampai aterm kemungkinan besar memiliki pengalaman kehamilan yang berbeda daripada mereka yang lebih tua. Sebanyak $33 \%$ dari remaja yang melahirkan adalah orang tua tunggal. Mereka yang berusia kurang 20 tahun yang berstatus menikah saat melahirkan 
memiliki resiko perceraian lebih tinggi dan ketidakharmonisan keluarga (Glasier, 2006).

Kehamilan pranikah pada remaja membuat mereka berhenti sekolah, dengan demikian gagal mencapai potensi pendidikannya secara penuh. Kesempatan memperoleh peluang kerja berkurang sehingga status sosialnya rendah. Mereka mengalami perasaan tertekan karena memperoleh sangsi sosial dari keluarga, teman dan lingkungan masyarakat. Mayoritas wanita yang mengalami kasus tersebut akan mengalami stres emosional akibat perasaan bersalah dan menyesal. Serta merasa terdiskriminasi dari pergaulannya yang nantinya dapat mereka refleksikan dengan mengkonsumsi alkohol, obat-obatan dan merokok (Manuaba, 2002).

Pengalaman kehamilan pranikah yang dihadapi seseorang akan membentuk sikap positif atau negative dari individu. Pembentukan sikap individu dapat didukung oleh mekanisme mental yang mengevaluasi, membentuk pandangan dan menentukan kecenderungan perilaku individu terhadap sesuatu yang sedang dihadapi.

Wilayah kerja Puskesmas Taman-Sidoarjo memiliki masyarakat yang heterogen terdiri dari penduduk asli dan pendatang dari luar kota Sidoarjo, seperti diantaranya Surabaya, Jakarta, Bandung, Malang, Kediri, Nganjuk, Tuban dan Madura. Sehingga dengan mudah terjadi pertukaraan kebudayaan yang kemudian diadopsi oleh remajanya, salah satunya hubungan seksual pranikah. Berdasarkan survei pendahuluan yang dilakukan, angka kejadian remaja yang mengalami kehamilan pranikah sebanyak 20 orang dan mereka masih melanjutkan kehamilannya. Namun, mayoritas dari mereka tidak mengetahui dampak dari kehamilan pranikah.

Berdasarkan kenyataan tersebut, peneliti ingin mengetahui bagaimana sikap primigravida pranikah terhadap kehamilannya agar dapat memberikan informasi kepada keluarga dan lingkungan sekitar untuk membantu primigravida pranikah beradaptasi dengan kehamilannya sehingga tidak mempengaruhi kesehatan ibu dan janin. Atas dasar latar belakang tersebut, diajukan rumusan masalah berikut. Bagaimanakah sikap primigravida pranikah terhadap kehamilannya di wilayah kerja Puskesmas Taman-Sidoarjo ?.

Penelitian ini bertujuan untuk menjelaskan hasil identifikasi sikap primigravida pranikah terhadap kehamilannya di wilayah kerja
Puskesmas Taman - Sidoarjo. Dan manfaat teoritis penelitian yaitu, sebagai acuhan dan pedoman tambahan untuk pengembangan ilmu pengetahuan serta penelitian yang selanjutnya yang bermanfaat untuk petugas kesehatan, mahasiswa, masyarakat dan pihak yang terkait dengan penelitian ini sehingga bisa memberikan dukungan dan membantu remaja yang mengalami kehamilan pranikah untuk beradaptasi dengan kehamilannya. Manfaat praktis penelitian adalah untuk meningkatkan pelayanan KIA oleh petugas kesehatan dengan melakukan pendekatan kepada primigravida pranikah serta memotivasi petugas kesehatan dan pihak terkait dalam penelitian ini untuk mensosialisasikan tentang kesehatan reproduksi dan untuk meningkatkan kemampuan mahasiswa dalam mengidentifikasi masalah.

\section{BAHAN DAN METODE}

Penelitian ini menggunakan metode penelitian deskriptif dengan desain survei cross sectional. Metode penelitian deskriptif adalah suatu penelitian yang dilakukan untuk mendeskripsikan atau menggambarkan suatu fenomena yang terjadi di dalam masyarakat. Desain penelitian survei cross sectional merupakan survei dengan cara pendekatan, observasi atau pengumpulan data sekaligus pada suatu saat, artinya tiap subjek penelitian hanya diobservasi sekali saja (Notoatmodjo, 2010).

Peneliti ingin mengetahui sikap primigravida pranikah terhadap kehamilannya secara objektif untuk menjawab permasalahan yang dihadapi sekarang ini.

Penelitian ini dilakukan di wilayah kerja Puskesmas Taman dan dilaksanakan pada bulan Juni-Juli 2013. Populasi dalam penelitian ini adalah 20 orang primigravida pranikah di wilayah kerja Puskesmas Taman-Sidoarjo.

Jumlah sampel yang digunakan dalam penelitian ini sebanyak 20 orang primigravida pranikah di wilayah kerja Puskesmas TamanSidoarjo.Penelitian ini termasuk dalam penelitian populasi sehingga dalam pengambilan sampel menggunakan seluruh populasi yang terdata.

Penelitian ini menggunakan kriteria inklusi yaitu primigravida pranikah dengan batas usia 15-24 tahun, primigravida pranikah yang masih melanjutkan kehamilannya dan bersedia menjadi responden. Kriteria inklusi adalah kriteria atau ciri-ciri yang perlu dipenuhi oleh 
setiap anggota populasi yang yang dapat diambil sebagai sampel (Notoatmodjo, 2010).

Dalam penelitian ini penulis menggunakan variabel sikap primigravida pranikah terhadap kehamilannya sebagai variabel tunggal.

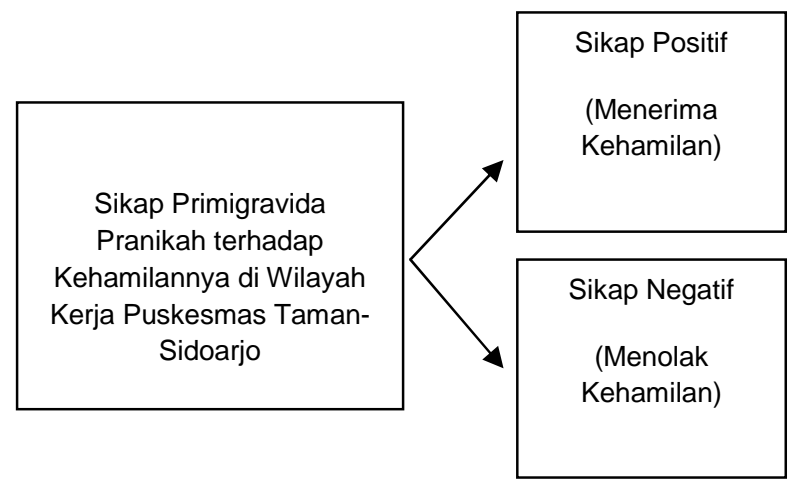

Gambar 1 - Kerangka Operasional

Instrumen yang digunakan dalam penelitian ini adalah kuesioner dengan pertanyaan tertutup. Metode pengumpulan data yang digunakan adalah peneliti mengajukan surat ijin penelitian dari instansi pendidikan kepada Kepala BAKESBANGPOL Kabupaten Sidoarjo dan Kepala DINKES Kabupaten Sidoarjo. Surat rekomendasi dari kedua instansi tersebut diserahkan kepada Kepala Puskesmas Taman dan Camat Taman.

Data jumlah primigravida pranikah di Kecamatan Taman didapatkan dari bidan koordinator di Puskesmas Taman, selanjutnya peneliti mendatangi rumah-rumah responden dengan didampingi oleh seorang kader yang sudah ditunjuk untuk menjelaskan maksud dan tujuan peneliti untuk melakukan wawancara kemudian memberikan lembar informed consent kepada responden.Setelah responden bersedia menandatangani lembar informed consent, peneliti membantu responden membacakan pertanyaan kuesioner yang merupakan pertanyaan tertutup untuk diisi dengan jawaban yang telah disediakan dan setelah kuesioner terkumpul, peneliti melakukan analisis data.

Analisis data dalam penelitian ini selalu berhubungan teknik pengolahan data yaitu : a.) Saat tes yang sudah diisi oleh responden diberikan kepada peneliti, peneliti akan melihat kembali kelengkapan jawaban yang diberikan oleh responden. Jika ada jawaban yang belum lengkap, peneliti akan mengembalikan tes tersebut kepada responden dan meminta untuk melengkapinya; b.) Pengkodean dilakukan dengan memberikan kode numerik (angka) pada tes untuk mempermudah penghitungan data; c.) Setelah melakukan pengeditan dan pengkodean pada hasil tes, peneliti akan memasukkan hasil jawaban ke dalam tabel. Dalam tabel tersebut, data akan disajikan dalam bentuk presentase.

Analisis data penelitian deskriptif ini menggunakan rumus rata-rata hitung (mean).

$$
\overline{(\mathrm{X}})=\frac{\sum x i}{n}
$$

Keterangan

$\mathrm{X}=$ rata-rata $\dot{\overline{\mathrm{hit}}}$ ung

$x_{i}=$ nilai dalam suatu sampel

$n=$ total banyaknya pengamatan dalam suatu sampel

\section{HASIL DAN PEMBAHASAN}

Upaya memperoleh data dalam penelitian ini dilakukan dengan cara menyebarkan kuesioner kepada responden dan kemudian kuesioner dikembalikan kepada peneliti untuk diolah. Pengolahan data dilakukan secara manual dengan menggunakan presentase. Penelitian ini termasuk dalam penelitian populasi karena sampel yang diambil adalah seluruh populasi yang terdata. Responden yang diteliti sebanyak 20 orang primigravida pranikah.

Hasil penelitian akan disajikan dalam dua bagian antara lain data umum dan data khusus. Data umum berupa karakteristik dari responden. Data khusus berupa sikap primigravida pranikah terhadap kehamilannya. Berdasarkan perhitungan diperoleh sebagai berikut :

\section{Data Umum}

Data umum berupa karakteristik dari responden, yakni berdasarkan umur, usia kehamilan, pendidikan dan pekerjaan.

Karakteristik responden berdasarkan umur berfungsi untuk mengetahui pada kisaran berapa usia primigravida pranikah sehingga dalam memberikan informasi bisa disesuaikan dengan umur agar informasi tepat sasaran. Berikut merupakan tabel dari kisaran umur primigravida pranikah. 


\begin{tabular}{cccc}
\hline No & Umur & $\mathrm{f}$ & $\%$ \\
\hline 1. & 16 Tahun & 2 & 10 \\
2. & 17 Tahun & 5 & 25 \\
3. & 18 Tahun & 3 & 15 \\
4. & 19 Tahun & 7 & 35 \\
5. & 20 Tahun & 3 & 15 \\
\hline & Total & 20 & 100
\end{tabular}

Tabel 2 - Distribusi frekuensi umur primigravida pranikah di wilayah kerja Puskesmas Taman-Sidoarjo

Tabel 2. dapat dijelaskan bahwa dari 20 responden, primigravida pranikah paling banyak berusia 19 tahun yaitu 7 orang (35\%) dan paling sedikit berusia16 tahun yaitu 2 orang (10\%).

Usia kehamilan merupakan tahapan masa kehamilan yang memiliki ciri-ciri tertentu. Setiap orang yang mengalami kehamilan akan merasakan setiap perubahan sesuai dengan pertambahan usia kehamilan.

Tahapan kehamilan dibagi menjadi 3, yakni trimester I, trimester II dan trimester III. Berikut tabel distribusi frekuensi usia kehamilan primigravida pranikah di wilayah kerja Puskesmas Taman-Sidoarjo.

\begin{tabular}{cccc}
\hline No & Usia Kehamilan & $\mathrm{f}$ & $\%$ \\
\hline 1. & Trimester I & 8 & 40 \\
2. & Trimester II & 7 & 35 \\
3. & Trimester III & 5 & 25 \\
\hline & Total & 20 & 100
\end{tabular}

Tabel 3 - Distribusi frekuensi usia kehamilan primigravida pranikah diwilayah kerja Puskesmas Taman-Sidoarjo

Tabel 3. dapat dijelaskan bahwa mayoritas responden masih dalam tahap trimester I sebanyak 8 orang $(40 \%)$, trimester II sebanyak 7 orang (35\%) dan trimester III sebanyak 5 orang $(25 \%)$.

Pendidikan merupakan proses untuk meningkatkan pengetahuan yang dimiliki seseorang. Semakin tinggi pendidikan orang tersebut maka bisa jadi semakin tinggi pula pengetahuan dan pengalaman yang dimiliki,sehingga dengan pengetahuan dan pengalaman tersebut seseorang bisa menentukan sikap terhadap suatu objek.

Tabel di bawah ini menjelaskan tentang distribusi frekuensi pendidikan primigravida pranikah di wilayah kerja Puskesmas TamanSidoarjo.

\begin{tabular}{cccc}
\hline No & Pendidikan & $\mathrm{f}$ & $\%$ \\
\hline 1. & SMP & 1 & 5 \\
2. & SMA & 19 & 95 \\
\hline & Total & 20 & 100
\end{tabular}

Tabel 4 - Distribusi frekuensi pendidikan primigravida pranikah di wilayah kerja Puskesmas Taman-Sidoarjo

Tabel 4. dapat dijelaskan bahwa pendidikan dari primigravida pranikah mayoritas berpendidikan SMA sebanyak 19 orang (95\%) dan berpendidikan SMP sebanyak 1 orang $(5 \%)$.

Pekerjaan dapat menentukan status sosial ekonomi seseorang di masyarakat. Dampak dari kehamilan pranikah salah satunya adalah pemutusan hubungan kerja (PHK). Status sosial ekonomi yang rendah dapat memperberat stress dan depresi yang seseorang rasakan selain karena kehamilan pranikah yang terjadi padanya.

Dibawah ini merupakan tabel frekuensi pekerjaan primigravida pranikah di wilayah kerja Puskesmas Taman-Sidoarjo.

\begin{tabular}{|c|c|c|c|}
\hline No & Pekerjaan & $f$ & $\%$ \\
\hline 1. & Wiraswasta & 3 & 15 \\
\hline 2. & Tidak Bekerja & 17 & 85 \\
\hline & Total & 20 & 100 \\
\hline
\end{tabular}

Tabel 5. dapat dijelaskan bahwa dari 20 primigravida pranikah, sebanyak 17 orang (85\%) tidak bekerja dan 3 orang (15\%) wiraswasta.

\section{Data Khusus}

Data khusus berupa sikap primigravida pranikah terhadap kehamilannya.

Sikap adalah reaksi perasaan menerima atau menolak terhadap suatu objek. Objek di dalam konteks ini adalah kehamilan pranikah jadi bagaimana sikap primigravida pranikah terhadap kehamilannya di wilayah kerja Puskesmas Taman-Sidoarjo.

Pada tabel dibawah ini akan dijelaskan bagaimana sikap primigravida pranikah terhadap kehamilannya.

\begin{tabular}{llll}
\hline No & Kategori & $f$ & $\%$ \\
\hline
\end{tabular}




\begin{tabular}{cccc}
\hline 1. & Positif & 9 & 45 \\
2. & Negatif & 11 & 55 \\
\hline & Total & 20 & 100
\end{tabular}

Tabel 6 - Distribusi frekuensi sikap primigravida pranikah di wilayah kerja Puskesmas Taman-Sidoarjo

Tabel 6. dapat dijelaskan bahwa dari 20 responden sebanyak 11 orang (55\%) primigravida pranikah menunjukkan sikap negatif (menolak) terhadap kehamilannya dan hanya 9 orang $(45 \%)$ primigravida pranikah menunjukkan sikap positif (menerima) terhadap kehamilannya.

Setelah data dianalisis, selanjutnya dilakukan pembahasan tentang sikap primigravida pranikah terhadap kehamilannya di wilayah kerja Puskesmas Taman-Sidoarjo.

\section{Karakteristik Responden Berdasarkan Umur}

Berdasarkan hasil kuesioner diketahui bahwa dari 20 responden, primigravida pranikah paling banyak berusia 19 tahun yaitu 7 orang $(35 \%)$ dan paling sedikit berusia 16 tahun yaitu 2 orang (10\%).

Menurut Suryoputro (2006), dari hasil penelitian yang dilakukan oleh berbagai institusi di Indonesia selama kurun waktu tahun 19932002 menemukan bahwa 5\%-10\% wanita muda usia 15-24 tahun yang tidak/ belum menikah, telah melakukan aktifitas seksual yang beresiko, akibatnya terjadi peningkatan kehamilan yang tidak diinginkan di kalangan remaja.

Menurut Sarwono (2012), faktor-faktor yang menyebabkan kehamilan pranikah pada remaja adalah meningkatnya hormonal yang dapat menyebabkan terjadi peningkatan hasrat seksual remaja dan peningkatan hasrat seksual tersebut membutuhkan penyaluran dalam bentuk tingkah laku seksual tertentu. Namun, penyaluran hasrat seksual tersebut tidak dapat segera dilakukan karena adanya penundaan usia perkawinan baik secara hukum karena adanya undang-undang tentang perkawinan yang menetapkan batas usia menikah, maupun karena norma sosial yang makin lama makin menuntut persyaratan tinggi untuk perkawinan (pendidikan, pekerjaan, persiapan fisik dan mental). Selain itu, adanya norma-norma agama dan sosial memberikan larangan untuk melakukan hubungan seksual sebelum menikah, bahkan larangannya berkembang kepada larangan berciuman dan masturbasi. Bagi remaja yang tidak dapat menahan diri akan terdapat kecenderungan untuk melanggar larangan-larangan tersebut, dan semakin bebasnya pergaulan remaja yang tidak diimbangi dengan informasi seks yang sesuai dengan usia dan kebutuhan remaja, sehingga saat terjadi kehamilan pranikah padaremaja mayoritas belum siap secara fisik maupun psikis.

Menurut penelitian ini kehamilan pranikah banyak terjadi pada wanita dengan rentang usia 15-24 tahun dikarenakan konsep diri yang kurang matang sehingga mempengaruhi sikap wanita tersebut terhadap kehamilannya. Mereka yang dalam pengembangan konsep diri mengikuti pola perilaku teman-teman atau orang terdekatnya tanpa melakukan filterisasi terhadap tindakan yang dilakukan, melibatkan diri dalam kenikmatan seksual, mengidentifikasi diri dengan teman-temannya seperti merokok, konsumsi alkohol, narkoba atau seks bebas akan menunjukkan sikap negatif (menolak) terhadap kehamilannya apabila wanita tersebut mengalami kehamilan pranikah.

\section{Karakteristik Responden Berdasarkan Usia Kehamilan}

Berdasarkan hasil kuesioner dapat diketahui bahwa primigravida pranikah mayoritas masih dalam tahap trimester I sebanyak 8 orang (40\%), trimester II sebanyak 7 orang $(35 \%)$ dan trimester III sebanyak 5 orang (25\%).

Menurut Ummi Hani, dkk. (2011), pada trimester awal biasa disebut sebagai periode penyesuaian di awal kehamilan. Pada periode ini akan muncul rasa ketidaknyamanan pada ibu misalnya mual-muntah, kelelahan, pusing dan sering buang air kecil, hal tersebut bisa juga memicu rasa membenci kehamilannya, merasakan kekecewaan, kecemasan dan kesedihan sehingga pada kehamilan yang tidak direncanakan dan tidak diinginkan rasa ketidaknyamanan itu akan dirasakan berlebihan daripada kehamilan yang direncanakan dan diinginkan. Pada beberapa wanita khususnya dengan kehamilan yang tidak direncanakan dan tidak diinginkan akan mengalami penolakan terhadap kehamilannya dan berusaha mengakhirinya.

Menurut Marmi (2011), kurang lebih 80\% wanita mengalami kekecewaan, penolakan, kecemasan, depresi dan kesedihan dalam menjalani kehamilan trimester awal. Bagi wanita yang telah merencanakan kehamilannya akan merasa suka cita. Akan tetapi bagi wanita yang mengalami kehamilan pranikah, mereka akan menunjukkan sikap negatif (menolak). 
Penelitian ini menunjukkan bahwa dari hasil jawaban kuesioner 11 orang mengganggap kehamilannya sebagai ancaman dan mereka sudah pernah mencoba mengakhiri kehamilan mereka dengan meminum jamujamuan serta sengaja melakukan aktifitas berat. Proses penyesuaian diri terhadap kehamilan pada kasus kehamilan yang tidak diinginkan dan direncanakan meningkatkan perasaan kecewa, stres, depresi serta kesedihan sehingga dibutuhkan dukungan dan motivasi keluarga serta masyarakat.

\section{Karakteristik Responden Berdasarkan Pendidikan}

Berdasarkan hasil kuesioner dapat diketahui bahwa primigravida pranikah mayoritas SMA sebanyak 19 orang (95\%) dan SMP sebanyak 1 orang (5\%).

Menurut penelitian yang telah dilakukan menunjukkan bahwa mayoritas minat seksual tertinggi terjadi pada pelajar SMA karena mereka mengalami masa pubertas yakni proses kematangan fisik dan psikis serta mengalami kematangan seks primer dan sekunder. Mulai timbulnya rasa suka pada lawan jenis dan keingintahuan yang besar terhadap suatu objek membuat para pelajar ini berusaha melakukan eksperimen seksual sesuai dengan keinginan mereka.

Menurut Marmi (2011), meningkatnya minat seksual membuat remaja selalu berusaha mencari lebih banyak informasi tentang seks. Orang tua dan masyarakat sering kali masih menganggap pendidikan seks sebagai hal yang tabu sehingga hanya sedikit remaja yang memperoleh pendidikan tentang seks yang benar sesuai umur dan kebutuhannya. Oleh karena itu, mereka selalu terdorong untuk mencari informasi seks melalui buku-buku seks dari temannya, internet, masturbasi, bercumbu atau melakukan senggama.

Dampak psikologi pada remaja yang mengalami kehamilan pranikah adalah mengalami putus sekolah sementara atau selamanya dan tersisih dari pergaulan karena tidak bisa membawa diri. Sehingga akan menunjukkan sikap negatif (menolak) terhadap kehamilannya karena mereka menganggap kehamilan itu merusak masa depan mereka.

\section{Karakteristik Responden Berdasarkan Pekerjaan}

Berdasarkan hasil kuesioner dapat diketahui bahwa dari 20 responden sebanyak
17 orang (85\%) tidak bekerja dan 3 orang $(15 \%)$ wiraswasta.

Menurut Susanti (2008), sumber stres dan depresi dapat disebabkan salah satunya karena masalah keuangan, pada responden yang tidak bekerja kondisi ini bisa memicu responden bersikap negatif (menolak) terhadap kehamilannya. Selain itu, karena tidak adanya kesibukan yang dilakukan responden membuat responden berpikir dan menyesali perbuatannya tersebut sehingga menyebabkan kebingungan dan semakin membenci kehamilannya.

Menurut penelitian yang telah dilakukan, tingkat stres dan depresi akibat mengalami kehamilan pranikah pada responden yang tidak bekerja lebih tinggi daripada yang bekerja. Dikarenakan ketika tidak bekerja/ tidak memiliki kesibukan responden selalu terbayang kesalahan di masa lalu sehingga membuat responden menarik diri dari interaksi dengan orang lain.

\section{Sikap Primigravida Pranikah terhadap Kehamilannya di Wilayah Kerja Puskesmas Taman-Sidoarjo}

Berdasarkan hasil kuesioner dapat diketahui bahwa sikap primigravida pranikah terhadap kehamilannya menunjukkan sikap negatif (menolak) yakni sebesar 55\% dari jumlah responden 20 orang sedangkan 45\% primigravida pranikah menunjukkan sikap positif (menerima) terhadap kehamilannya.

Kenyataannya primigravida pranikah merasa belum siap menghadapi kehamilannya, merasa takut, cemas dan ragu terhadap peran baru sampai terjadi peningkatan depresi dan stres.

Menurut Azwar (2011), sikap yang ditunjukkan oleh responden tersebut dipengaruhi oleh pengalaman pribadi sehingga terbentuk interaksi sosial yang negatif di dalam masyarakat. Selain itu pengaruh orang lain yang dianggap penting, misalnya sahabat, keluarga, ayah dari bayi yang dikandung dan masyarakat di lingkungan responden sangat mempengaruhi sikap yang ditunjukkan responden terhadap kehamilannya.

Kebudayaan, media massa yang memberikan pesan-pesan bersifat sugesti dapat mengarahkan opini responden sehingga menunjukkan sikap positif atau negatif. Faktor emosional membentuk prasangka yang merupakan sikap negatif yang didasari kelainan kepribadian pada orang-orang yang sangat 
frustasi. Prasangka didasari oleh rasa ketakutan yang berlebihan dalam diri individuserta perasaan ketidaknyamanan dan ketidakberdayaan dalam mempertahankan diri dari lingkungan yang dianggap tidak menerima keberadaannya.

Hasil penelitian ini, responden menunjukkan sikap negatif (menolak) terhadap kehamilannya namun tetap melanjutkan kehamilannya dengan perasaan yang mengalami stres dan depresi, ketidaknyamanan fisik, ketidakpuasan dengan bentuk tubuh, perubahan perasaan yang berlebihan dan kesulitan menerima perubahan akibat kehamilan bahkan membenci kehamilannya karena hasil jawaban kuesioner dari 10 orang yang memiliki hubungan baik dengan keluarga dan masyarakat hanya 7 orang yang mendapatkan dukungan dari keluarga dan masyarakat tentang kehamilannya sehingga dibutuhkan dukungan, perhatian dan motivasi dari orang lain yang dianggap penting oleh responden seperti sahabat, keluarga, ayah dari bayi yang dikandung dan masyarakat di lingkungan responden. Agar responden bisa beradaptasi dengan kehamilannya.

\section{SIMPULAN DAN SARAN}

Berdasarkan penelitian diatas dapat ditarik suatu kesimpulan mengenai sikap primigravida pranikah terhadap kehamilannya di wilayah kerja Puskesmas Taman-Sidoarjo mayoritas menunjukkan sikap negatif (menolak) kehamilannya sebanyak 11 orang (55\%) namun responden tetap melanjutkan kehamilan mereka dengan perasaan tidak nyaman, merasa stres dan depresi, bahkan membenci kehamilannya.

Saran yang dapat diberikan bagi petugas kesehatan, yaitu disarankan meningkatkan pelayanan memberikan asuhan kebidanan pada klien yang mengalami kehamilan pranikah; bagi institusi pendidikan, yaitu diharapkan dapat memberikan referensi dan bahan dokumentasi ilmiah dalam mengembangkan ilmu kebidanan tentang asuhan kebidanan pada primigravida pranikah; bagi keluarga dan masyarakat, yaitu disarankan untuk tidak melakukan diskriminasi dan mengacuhkan responden tapi memberikan dukungan dan membantu responden untuk beradaptasi dengan kehamilannya; bagi responden, adalah diharapkan hasil penelitian ini dapat memotivasi dan membantu beradaptasi dengan kehamilannya; serta bagi penelitian selanjutnya, agar dapat diharapkan penelitian ini bermanfaat sebagai bahan pembanding bagi penelitian selanjutnya dan juga dapat mengembangkan variabel penelitian dan jumlah sampel penelitian.

\section{DAFTAR PUSTAKA}

Ali, Muhammad. 2008. Psikologi Remaja. Jakarta: Bumi Aksara

Azwar, Saifuddin. 2011. Sikap Manusia Teori dan Pengukurannya. Yogyakarta: Pustaka Pelajar

Glasier, Anna dan Alisa Gebbie. 2006. Keluarga Berencana dan Kesehatan Reproduksi. Jakarta: EGC

Hani, Ummi., dkk. 2011. Asuhan Kebidanan Pada Kehamilan Fisiologis. Jakarta: Salemba Medika

Hidayat, A. Aziz Alimatul. Metode Penelitian Kebidanan \& Teknik Analisis Data. Jakarta : Salemba Medika

Iskandar. 2008. Metodologi Penelitian Pendidikan dan Sosial (Kuantitatif dan Kuaitatif). Jakarta: Gaung Persada Press

Kusmiran, Eny. 2012. Kesehatan Reproduksi Remaja dan Wanita. Jakarta: Salemba Medika

Kusyanti, Tatik dkk. 2012. Menjawab Pertanyaan dalam Praktik Klinik Kebidanan (PKK). Jakarta: TIM

Lia, Vivian Nanny dan Tri Sunarsih. 2011. Asuhan Kehamilan untuk Kebidanan. Jakarta: Salemba Medika

Manuaba, I. A. Chandranita. 2002. Gawat Darurat Obstetri-Ginekologi dan Obstetri-Ginekologi Sosial. Jakarta: EGC

Marmi. 2011. Asuhan Kebidanan Pada Masa Antenatal. Yogyakarta: Pustaka Pelajar

Nasir, Abd., dkk. 2011. Buku Ajar Metodologi Penelitian Kesehatan: Konsep Pembuatan Karya Tulis dan Thesis untuk Mahasiswa Kesehatan. Yogyakarta: Nuha Medika 
Nursalam. 2008. Konsep dan Penerapan Metodologi Penelitian IImu Keperawatan. Jakarta: Salemba Media

Notoatmodjo, Soekidjo. 2010. Metodologi Penelitian Kesehatan. Jakarta: Rineka Cipta

Pieter, Herri Zan \& Namora Lumongga Lubis. 2011. Pengantar Psikologi Untuk Kebidanan. Jakarta: Kencana

Romauli, Suryati. 2011. Buku Ajar ASKEB I: Konsep Dasar Asuhan Kehamilan. Yogyakarta: Nuha Medika

Prawirohardjo, Sarwono. 2009. Ilmu Kebidanan. Jakarta: Yayasan Bina Pustaka Sarwono Prawirohardjo

Prawirohardjo, Sarwono. 2010. Pelayanan Kesehatan Maternal dan Neonatal. Jakarta: Yayasan Bina Pustaka Sarwono Prawirohardjo

Sarwono, Sarlito Wirawan. 2012. Psikologi Remaja. Jakarta: Raja Grafindo Persada Susanti, Ni Neng. 2008. Psikologi Kehamilan. Jakarta: EGC 